\title{
TRH-Receptor-Type-2-Deficient Mice are Euthyroid and Exhibit Increased Depression and Reduced Anxiety Phenotypes
}

\author{
Yuhua Sun', Bojana Zupan², Bruce M Raaka', Miklos Toth² and Marvin C Gershengorn*,' \\ 'Clinical Endocrinology Branch, National Institute of Diabetes and Digestive and Kidney Diseases, National Institutes of Health, Bethesda, MD, \\ USA; ${ }^{2}$ Department of Pharmacology, Weill Cornell Medical College, New York, NY, USA
}

\begin{abstract}
Thyrotropin-releasing hormone $(\mathrm{TRH})$ is a neuropeptide that initiates its effects in mice by interacting with two G-protein-coupled receptors, TRH receptor type I (TRH-RI) and TRH receptor type 2 (TRH-R2). Two previous reports described the effects of deleting $\mathrm{TRH}-\mathrm{RI}$ in mice. TRH-RI knockout mice exhibit hypothyroidism, hyperglycemia, and increased depression and anxiety-like behavior. Here we report the generation of TRH-R2 knockout mice. The phenotype of these mice was characterized using gross and histological analyses along with blood hematological assays and chemistries. Standard metabolic tests to assess glucose and insulin tolerance were performed. Behavioral testing included elevated plus maze, open field, tail suspension, forced swim, and novelty-induced hypophagia tests. TRH-R2 knockout mice are euthyroid with normal basal and TRH-stimulated serum levels of thyroid-stimulating hormone (thyrotropin), are normoglycemic, and exhibit normal development and growth. Female, but not male, TRH-R2 knockout mice exhibit moderately increased depression-like and reduced anxiety-like phenotypes. Because the behavioral changes in TRH-RI knockout mice may have been caused secondarily by their hypothyroidism whereas TRH-R2 knockout mice are euthyroid, these data provide the first evidence for the involvement of the TRH/TRH-R system, specifically extrahypothalamic TRH/TRH-R2, in regulating mood and affect. Neuropsychopharmacology (2009) 34, I60 I- 1608; doi:I0.1038/npp.2008.217; published online 10 December 2008
\end{abstract}

Keywords: thyrotropin-releasing hormone; thyrotropin-releasing hormone receptors; depression; anxiety; behavioral changes; TRHR2-deficient mouse

\section{INTRODUCTION}

Thyrotropin-releasing hormone (TRH) is a tripeptide agonist that initiates its effects by activating two G-protein-coupled receptors, TRH receptor type 1 (TRHR1) and TRH receptor type 2 (TRH-R2) (see Sun et al, 2003 for review). Activation of these receptors appears to initiate a number of effects within the central nervous system. TRH receptors are expressed in the anterior pituitary and respond to hypothalamic TRH by activating the hypothalamic-pituitary-thyroid (HPT) axis and consequently regulating metabolism. TRH and its corresponding receptors are also expressed extrahypothalamically in various brain regions including the limbic system and cortex. Because of its presence outside the HPT axis, TRH is also considered a neurotransmitter or neuromodulator (Gary et al, 2003). The function of extrahypothalamic TRH has

\footnotetext{
*Correspondence: Dr MC Gershengorn, National Institute of Diabetes and Digestive and Kidney Diseases, National Institutes of Health, 50 South Drive, Room 4134, Bethesda, MD 20892-8029, USA, Tel: + I 30145 | 6305, Fax: + I 3014804214 ,

E-mail: marving@intra.niddk.nih.gov

Received 26 September 2008; revised 13 November 2008; accepted 13 November 2008
}

been inferred from pharmacological studies using TRH and its analogues showing a wide array of actions including arousal, increased locomotor activity (LA), antidepressant and anxiolytic effects (Pekary et al, 2005; Sattin, 1999; Gutierrez-Mariscal et al, 2008).

Studies have linked TRH and its receptors to psychiatric disorders. Hypothyroidism causes depression, loss of energy, and weight gain and within the HPT axis, a number of subtle abnormalities have been found in individuals with major depression including blunted thyroid-stimulating hormone (TSH) response to TRH and absence of nocturnal TSH surge (Bartalena et al, 1990). Also, decreased TRH gene expression was observed in the hypothalamus of depressed patients (Alkemade et al, 2003). TRH and its receptors in the limbic system and cortex are believed to mediate the endogenous and exogenous effects of TRH on affect, mood, and arousal (Gary et al, 2003; Yarbrough et al, 2007) but it has been notoriously difficult to separate the hypothalamic and extrahypothalamic functions of TRH and to assign specific functions and behaviors to extrahypothalamic TRH.

TRH-R1 was initially cloned from a mouse pituitary tumor cDNA library (Straub et al, 1990) and then orthologous receptors were cloned from a number of different species, including rat (de la Pena et al, 1992; 
Zhao et al, 1992; Sellar et al, 1993), chicken (Sun et al, 1998), cow (Takata et al, 1998), Catostomus commersoni (Harder et al, 2001a,b), and humans (Duthie et al, 1993; Matre et al, 1993). The human TRH-R1 is 90 and $89 \%$ homologous to the mouse and rat receptors at the DNA level, respectively; the three receptors exhibit approximately 95\% homology at the amino-acid level. TRH-R2 was identified in rat (Cao et al, 1998; Itadani et al, 1998; O'Dowd et al, 2000), mouse (Harder et al, 2001a,b), and $C$. commersoni (Harder et al, 2001a,b); TRH-R2 has not been described in humans. Amino-acid sequence alignments of the two types of TRH receptors from the same species reveal a $50 \%$ overall identity. TRH-R1 and TRH-R2 bind TRH with equal affinities but exhibit a different distribution of expression in rats. In particular, TRH-R1 is expressed at high levels whereas TRH-R2 is not expressed or expressed at very low levels within the anterior pituitary gland, and the distribution of their expression within the rat brain is mostly nonoverlapping. Of note, TRH-R2 is expressed within the limbic system (O'Dowd et al, 2000).

Two previous reports described the generation and characterization of TRH-R1-deficient mice (Rabeler et al, 2004; Zeng et al, 2007). TRH-R1-deficient mice exhibit 'tertiary hypothyroidism' with low levels of thyroid hormones, and mild hyperglycemia. Zeng et al found that the TRH-R1-deficient mice they generated, in contrast to those generated by Rabeler et al, did not exhibit developmental abnormalities but displayed increased depressionlike and increased anxiety-like behaviors. Because the mice studied by Zeng et al were hypothyroid, it is not possible to determine whether the depression- and anxiety-like signs were caused by TRH-R1 deficiency outside the HPT axis or the changes associated with tertiary hypothyroidism. TRHdeficient mice have been generated and characterized also (Yamada et al, 1997). Similar to TRH-R1-deficient mice, TRH-deficient mice are hypothyroid and hyperglycemic. To our knowledge, no behavioral studies of TRH-deficient mice have been reported.

Herein we report the generation and characterization of TRH-R2 knockout (ko) mice. We show that TRH-R2deficient mice are euthyroid with normal thyroxine and normal basal and TRH-stimulated serum levels of TSH (thyrotropin), are normoglycemic, and exhibit normal development and growth. Interestingly, female, but not male, TRH-R2 ko mice exhibit moderately increased depression-like and reduced anxiety-like phenotypes.

\section{MATERIALS AND METHODS}

\section{Construction of Targeting Vector and Generation of TRH-R2 Knockout Mice}

Genomic clones spanning the entire mouse $T R H-R 2$ gene were isolated by screening a BAC mouse genomic library (129/SvJ, Bac Mouse I PCR library screening service; Genome Systems Inc., St Louis, Missouri) with primers specific for the third exon (sense primer: $5^{\prime}$-TTTCCT GGACCCCTGGGGTCCTGCTG-3'; anti-sense primer: $5^{\prime}$-GG GAAGCAGCTGCTGCTGGACCTGAGAC- $3^{\prime}$ ). The clones were characterized in detail by standard molecular biology techniques. A $13 \mathrm{~kb}$ BglII-BglII DNA fragment including the $T R H-R 2$ gene missing the first exon and the first $130 \mathrm{bp}$ of the first intron were subcloned into the BamHI site of the pBluescript SK II(-) vector (Stratagene). A 1243 bp DNA fragment including the second exon and the second intron was subcloned into the EcoRI-BamHI sites of the pLoxpneo vector (Yang et al, 1998). The resulting construct was cleaved with $H p a \mathrm{I}$ and NotI followed by insertion of a $9 \mathrm{~kb}$ DNA fragment that is $3^{\prime}$ to the third exon of the TRH-R2 gene. The replacement vector finally contained $10.2 \mathrm{~kb}$ of homologous genomic DNA in which the third exon of the $T R H-R 2$ gene was removed and replaced by a loxp-Neo-loxp cassette. The finished construct, pTRH-R2neo, is shown in Figure 1.

TC1 embryonic stem (ES) cells (Deng et al, 1996) were transfected with NotI-digested $p T R H-R 2$ neo and selected with G418 and 1-(2-deoxy-2-fluoro- $\beta$-D-arabinofuranosyl-5iodouracil (FIAU). ES cell colonies that were resistant to both G418 and FIAU were analyzed by Southern blotting for homologous recombination events within the TRH-R2 locus. Genomic DNAs from these clones and the parental TC1 cell line were digested with EcoRI and EcoRV and then probed with a $5^{\prime}$-flanking probe specific to the $T R H-R 2$ gene. The $5^{\prime}$ probe is a $416 \mathrm{bp} S m a I-S m a I$ fragment. Homologous recombinant cell clones were identified by Southern blot analysis as described below. These ES cells were injected into 3.5-day-old 129/Svev blastocysts that were subsequently implanted into pseudopregnant recipients. The resulting chimeras were mated with $129 / \mathrm{Svev}$ females and germ-line transmission of the mutant allele was identified by Southern blot analysis. The mutant mice were backcrossed four times to the 129 background.

\section{Genotype Determination}

For DNA preparation, ES cells or mouse tails were incubated overnight at $55^{\circ} \mathrm{C}$ in extraction buffer $(100 \mathrm{mM}$ Tris $\mathrm{HCl}, \mathrm{pH} 8.5,200 \mathrm{mM} \mathrm{NaCl}, 5 \mathrm{mM}$ EDTA, $0.2 \%$ SDS, and $200 \mu \mathrm{g} / \mathrm{ml}$ proteinase $\mathrm{K}$ ) followed by $15 \mathrm{~min}$ at $80^{\circ} \mathrm{C}$.

\section{Southern Blot}

The DIG High Prime DNA Labeling and Detection Starter Kit II (Roche Molecular Biochemicals, Mannheim, Germany) was used for Southern blot assay. Briefly, DNA $(10 \mu \mathrm{g})$ was digested with EcoRI and EcoRV, size separated on a $0.8 \%$ agarose gel, and then capillary-transferred to a nylon membrane (Hybond N; Amersham Bioscience, Braunschweig, Germany). The membranes were hybridized using a probe that was a digoxigenin-labeled 416 bp SmaISmaI fragment specific for a region upstream of the third exon of the TRH-R2 gene that was not included in the targeting vector. Signals were analyzed by exposing to X-ray film (Eastman Kodak Company, Rochester, NY).

\section{PCR Analysis}

PCR was carried out by using the Expand Long Template PCR System (Roche Molecular Biochemicals). The primer pair generating an $800 \mathrm{bp}$ product specific for the wild-type gene was-sense: $5^{\prime}$-GGGCAGCCTTCCTGA AACTGTGCTGGTGCCGGGCAG-3'; anti-sense: $5^{\prime}$-CTTGC ACATTCGGGGTCAAGTGGCTTCTTGATGGAG-3' . The primer pair generating a $1200 \mathrm{bp}$ product specific for the neo 

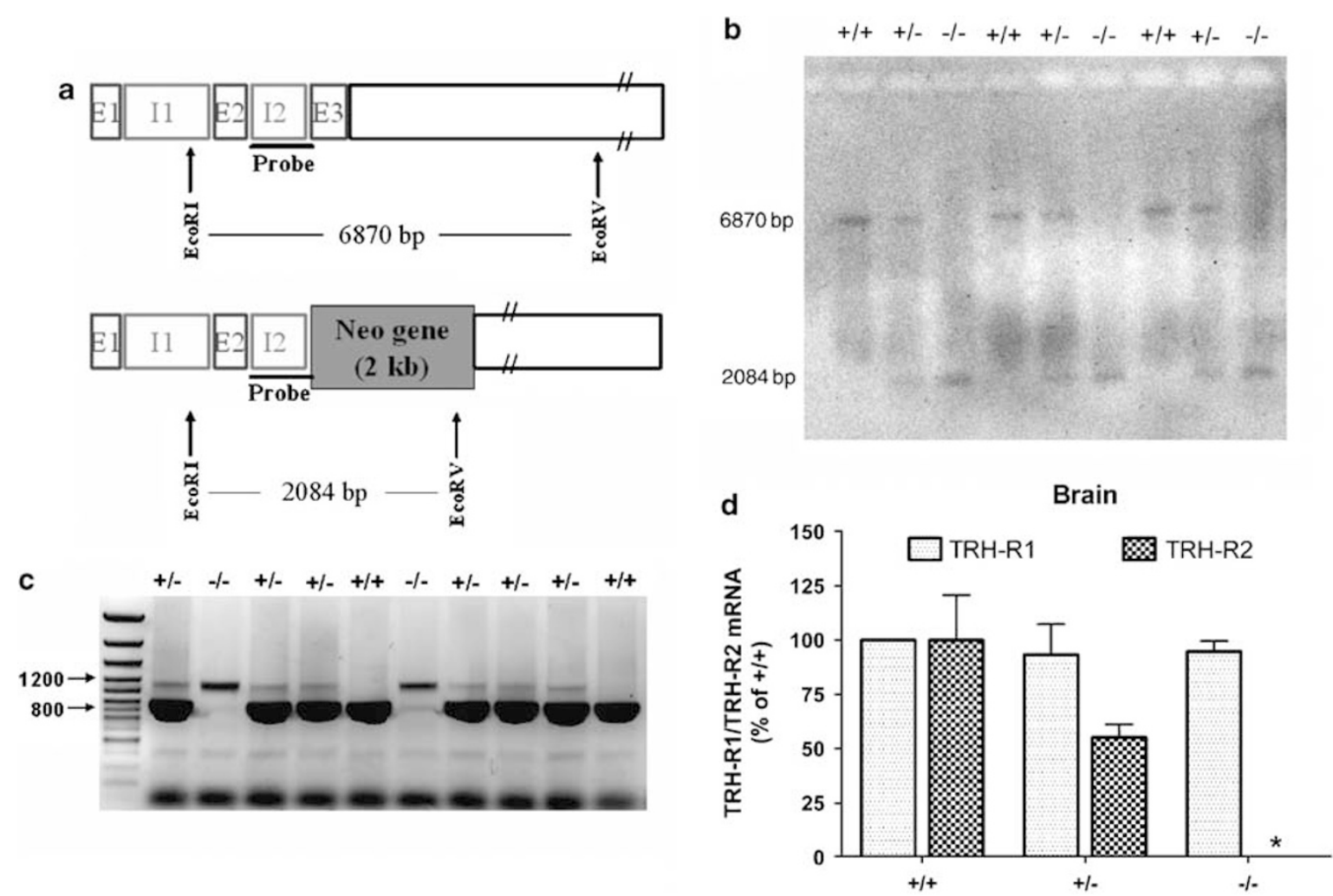

Figure I Targeting vector for thyrotropin-releasing hormone receptor type 2 (TRH-R2) knockout and genotyping. Schematic representation of the targeting vector (a). EI, 2, 3-exon I, 2, 3; II, 2-intron I, 2. Representative Southern blot (b) and PCR (c) analysis of wild-type (+ / +), heterozygous $(+/-)$, and homozygous mice $(-/-)$. qRT-PCR analysis of whole brain mRNA (d). The asterisk indicates that no TRH-R2 mRNA was detected in homozygous mice $(-1-)$.

gene was - sense: 5'-GACGTGACAAATGGAAAGTAGCAC GTCTCACTAGTC-3'; anti-sense: 5'-CAGAAGAACTCGTCA AGAAGGCGATAGAAGGCGATG-3'.

\section{Quantitative RT-PCR}

Total RNA was purified, reverse-transcribed, and transcript levels of selected genes were measured by qRT-PCR. In brief, total brain RNA was purified using an RNeasy Mini Kit (Qiagen) and first-strand cDNA was prepared using a High Capacity cDNA Archive Kit (Applied Biosystems). PCR was performed in $25 \mu \mathrm{l}$ reactions in 96-well plates using cDNA prepared from $100 \mathrm{ng}$ of total RNA and Universal PCR Master Mix (Applied Biosystems). Primers and probes were Assay-on-Demand (Applied Biosystems). The $C_{\mathrm{t}}$ values for TRH-R mRNAs were normalized to GAPDH and the levels measured in wild-type mice $\left(C_{\mathrm{t}}=25\right.$ for TRHR1 and TRH-R2) were set at $100 \%$. The levels of TRH-R2 mRNA in TRH-R2 $-/-$ mice were undetectable $\left(C_{\mathrm{t}}>37\right)$.

\section{Animal Care}

All animal protocols used in these studies were approved by the National Institute of Diabetes and Digestive and Kidney Diseases and the Weill Cornell Medical College Animal Care and Use Committees. We housed mice in microisolator cages (Labproducts) in a specific pathogen-free barrier facility with an air shower entrance.

\section{Pathology Analysis and Blood Chemistries}

Gross and histological analyses, and blood hematological assays and chemistries were performed by the Office of Research Services/Division of Veterinary Resources, National Institutes of Health.

\section{Metabolic Testing}

Analyses of growth and glucose/insulin homeostasis including glucose and insulin tolerance tests on normal and high-fat diets were performed by the Mouse Metabolism Laboratory of the National Institute of Diabetes and Digestive and Kidney Diseases Intramural Research Program under the direction of Dr Oksana Gavrilova. Glucose tolerance test: mice were fasted for $14-16 \mathrm{~h}$. Sterile glucose $(2 \mathrm{~g} / \mathrm{kg}$; dissolved in phosphate-buffered saline; volume: $0.1-0.2 \mathrm{ml}$ per mouse) was injected at time zero (i.p. glucose tolerance test). Blood samples $(20-30 \mu \mathrm{l})$ were taken from the tail vein just before the injection $(0 \mathrm{~min}), 15$, 30,60 , and $120 \mathrm{~min}$ after the glucose injection. Blood glucose and insulin levels were determined. Insulin tolerance test: freely fed mice were injected i.p. with human insulin $(0.75 \mathrm{U} / \mathrm{kg})$. Blood samples $(20-30 \mu \mathrm{l})$ were taken from the tail vein just before the injection $(0 \mathrm{~min})$ and $15,30,60$, and $120 \mathrm{~min}$ after the insulin injection. Blood glucose levels were measured with Glucometer Elite (Bayer Healthcare). 


\section{Thyroxine, TSH, and Prolactin}

Serum thyroxine was assayed by Gammacoat Total T4 Radioimmunoassay Kit (DiaSorin Inc., Stillwater, MN). Serum TSH levels were measured in blood obtained by retro-orbital sampling before (basal) and $30 \mathrm{~min}$ after i.p. injection of TRH $(5 \mu \mathrm{g} / \mathrm{kg})$. TSH was measured by radioimmunoassay using highly purified rat TSH (AFP11542B) for radioiodination, guinea pig anti-TSH antibody (AFP98991), and mouse TSH reference preparation (AFP51718MP). Serum prolactin was assayed using mouse prolactin (AFP10777D) for radioiodination, rabbit antimouse prolactin antibody (AFP131078), and mouse prolactin reference standard (AFP6476C). TSH and prolactin measurements were performed by Dr AF Parlow of the NIDDK National Hormone and Pituitary Program.

\section{Behavioral Testing}

TRH-R $2+I+$ and $-I-$ male and female littermates (8- to 12 -week old) were tested in elevated plus maze (EPM), open field (OF), tail suspension test (TST), forced swim test (FST), and in the novelty-induced hypophagia test (NIHT). Mice were also tested for LA and prepulse inhibition (PPI). Three cohorts were tested in the following order-cohort 1 : (i) EPM, (ii) OF, (iii) LA, (iv) PPI, and (v) FST; cohorts 2 and 3: (i) FST, (ii) TST, and (iii) NIHT. EPM, OF, LA, and PPI data are not reported because no differences between the groups were found. Only one procedure was conducted per day.

\section{TST}

Mice were individually suspended by the tail using adhesive tape for $6 \mathrm{~min}$. The session was videotaped and immobility was scored between 2 and $6 \mathrm{~min}$ by a trained observer who was blind to the genotype and data for male and female mice were analyzed separately by $t$-test.

\section{FST}

Mice were placed in a clear, water-filled cylinder (diameter, 8 inch; depth, 5 inch) for 6 min (Porsolt et al, 1978) and immobility time of the mice was measured between 2 and $6 \mathrm{~min}$ from a recorded videotape. Water temperature was equilibrated to room temperature of $21^{\circ} \mathrm{C}$. Mice were tested by an observer who was blind to the genotype of the mice. The data for male and female mice were analyzed separately by $t$-test.

\section{NIHT}

The test consists of 3 days of training in the home cage followed by testing in the home cage and then in a novel cage environment. Littermates were single-housed for 3 days before training began. Then, for 3 consecutive days mice were presented with sweetened condensed milk (Carnation) diluted 1-3 with water for $30 \mathrm{~min}$ each day in LM Animal Farms Quick Quench Universal Water Bottle ( 5 oz; Petco) essentially as described by Dulawa et al (2004). Home cage testing occurred on day 4 by presenting the milk for $10 \mathrm{~min}$ in the dark and the latency to drink and the duration of drinking were recorded (dark or home cage latency and duration). Novel cage testing was carried out on day 5 under bright lighting conditions and by placing the mice into new clean cages of the same dimensions as the home cage but without bedding. Latency to drink and duration of drinking were again recorded (light or novel cage latency and duration). All sessions were videotaped and scored by a trained observer who was blind to the genotype of the mice. Mice were tested only once. Statistical significance in the measures of latency and duration of drinking between TRH-R $2+I+$ and $-I-$ littermates was established by $t$-test. The data for males and females were analyzed separately.

\section{RESULTS}

\section{Generation of TRH-R2-Deficient Mice}

As shown in Figure 1a, the targeting vector was designed to delete exon 3 of the TRH-R2 coding region. Exon 3 was replaced by the neomycin-resistant gene. Homologous recombinants of the stably transfected ES clones obtained after antibiotic selection were identified by Southern analysis. Male chimeras generated by blastula injection were bred with $129 \mathrm{Svev}$ females with successful germ-line transmission. The heterozygous mice (TRH-R $2+I-)$ were apparently normal and subsequently gave rise to mice homozygous (TRH-R2-l-) for the mutant TRH-R2 locus with the expected frequency, indicating that the deletion of the $T R H-R 2$ gene did not result in embryonic lethality. The animals were genotyped by Southern blot (Figure $1 \mathrm{~b}$ ) and by PCR (Figure 1c) using the probe and primers described in Materials and methods, respectively. Quantitative RTPCR of brain RNA showed that TRH-R1 mRNA levels were the same in wild-type, heterozygous, and homozygous mutants whereas heterozygous mice exhibited $55 \%$ of the level of TRH-R2 mRNA found in wild-type mice and the ko mice did not express any TRH-R2 mRNA (Figure 1d). It is noteworthy that TRH-R2-I- mice exhibited the same level of TRH-R1 as wild-type mice even though they did not express TRH-R2.

\section{General Characterization of TRH-R2-/- Mice}

Male and female fertility in the TRH-R2-I- mice appeared normal; litter size was not affected. There was no difference in body weight at birth irrespective of the genotype of the mothers. Wild-type and TRH-R2-/- littermate mice of both genders exhibited similar growth rates on normal and high-fat diets. Adult TRH-R2-I- mice exhibited no pathology different from wild-type littermates. There were no differences in body weights and organ weights of adult wild-type and TRH-R2-I- mice. Routine blood chemistries were within normal limits and there were no differences between wild-type and TRH-R2-I- mice.

\section{Metabolic Testing}

On both a normal and high-fat diet, both male and female TRH-R2-I- mice exhibited normal glucose and insulin levels (Figure 2). TRH-R2 $-/-$ mice exhibited normal glucose and insulin tolerance tests also (data not shown). 

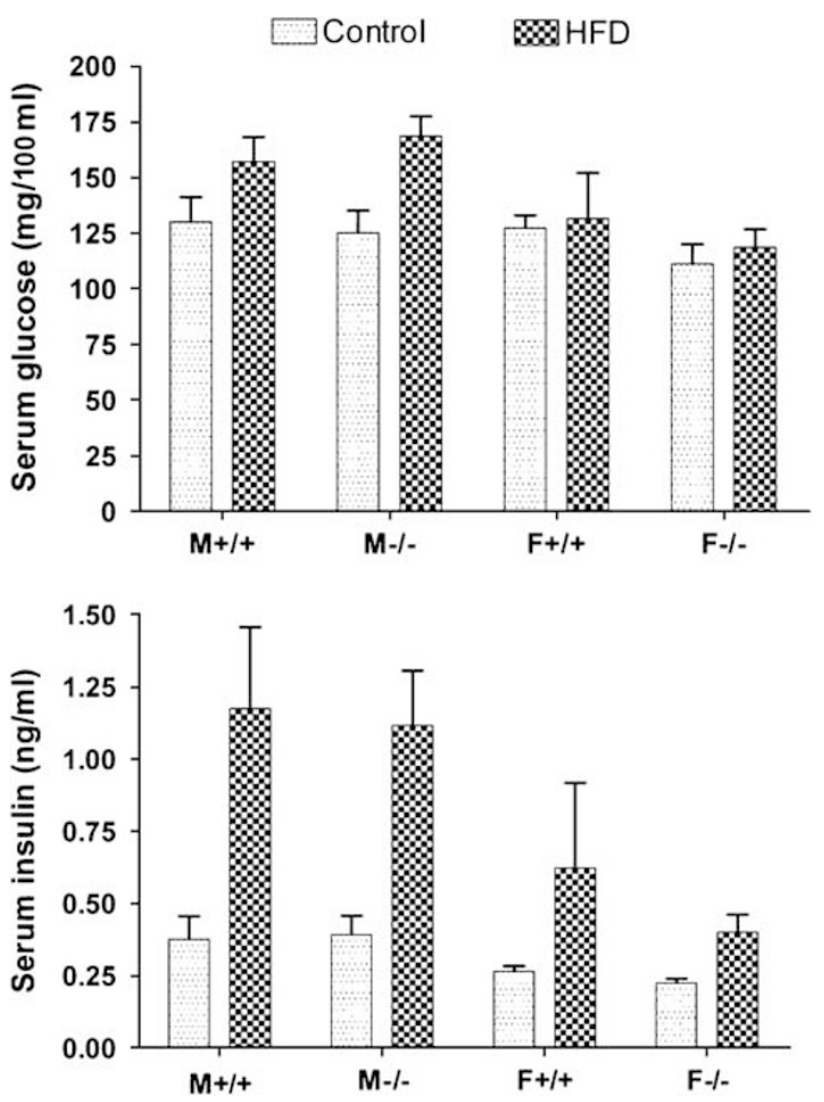

Figure 2 Serum glucose and insulin levels in wild-type and thyrotropinreleasing hormone receptor type 2 (TRH-R2)-deficient mice on normal (Control) and high-fat diets (HFD). TRH-R2 knockout mice exhibit normal glucose (upper panel) and insulin levels (lower panel) on Control and HFD. There was no difference in any of the values in wild-type compared to TRH-R2-deficient mice.

\section{Thyroxine, TSH, and Prolactin}

Serum thyroxine levels in male and female TRH-R2-Imice were not different from controls: male wild type, $4.7 \pm 0.21 \mu \mathrm{g}$ per $100 \mathrm{ml}$; male ko, $4.0 \pm 0.20 \mu \mathrm{g}$ per $100 \mathrm{ml}$; female wild type, $2.4 \pm 0.10 \mu \mathrm{g}$ per $100 \mathrm{ml}$; and female ko, $2.60 \pm 0.33 \mu \mathrm{g}$ per $100 \mathrm{ml}$. Serum TSH levels were not different basally and responded to TRH with a similar increase in TSH in wild-type and TRH-R2- $/-$ mice of both genders (Figure 3). Serum prolactin levels were not different from controls: male wild type, $8.5 \pm 2.3 \mathrm{ng} / \mathrm{ml}$; male ko, $5.5 \pm 0.71 \mathrm{ng} / \mathrm{ml}$; female wild type, $49 \pm 29 \mathrm{ng} / \mathrm{ml}$; and female ko, $62 \pm 19 \mathrm{ng} / \mathrm{ml}$.

\section{Behavioral Testing}

As TRH has been linked to mood and anxiety disorders (Gary et al, 2003; Sattin, 1999; Gutierrez-Mariscal et al, 2008), TRH-R2-I- mice were tested in depression and anxiety-related behavioral paradigms. The TST and FST are validated behavioral assays for assessing antidepressant activity. In these tests, animals are subjected to short-term inescapable stress that normally elicits a rapid adaptation to immobile posture sometimes called 'behavioral despair'. Immobility time is reduced by the acute administration of antidepressants and, as an extension of this finding,

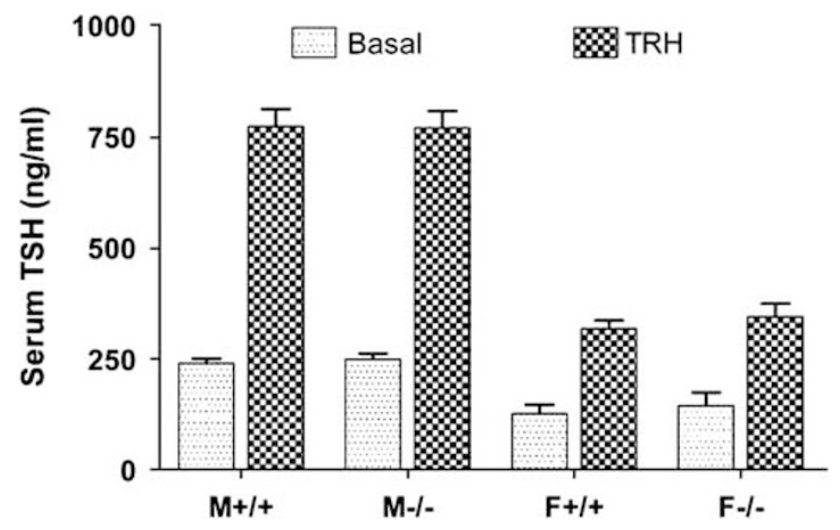

Figure 3 Basal and thyrotropin-releasing hormone (TRH)-stimulated serum thyroid-stimulating hormone (TSH) levels in wild-type and TRH receptor type 2 (TRH-R2)-deficient mice. Serum for TSH measurements was obtained just before TRH $(5 \mu \mathrm{g} / \mathrm{kg})$ administration i.p. (Basal) and 30 min after $(\mathrm{TRH})$. There was no difference in any of the values in wildtype compared to TRH-R2-deficient mice.

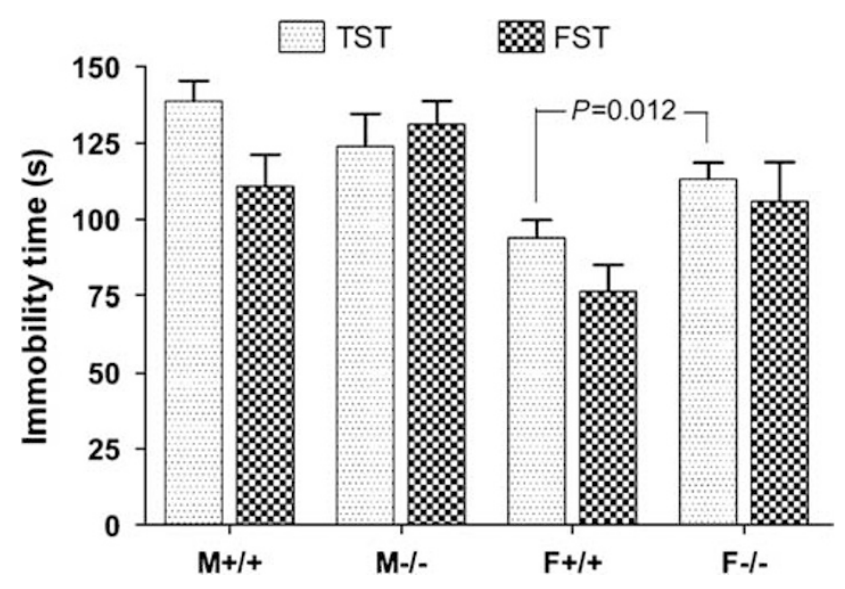

Figure 4 Results of tail suspension and forced swim tests in wild-type and thyrotropin-releasing hormone receptor type 2 (TRH-R2)-deficient mice. Forced swim (FST) and tail suspension tests (TST) were performed as described in Materials and methods. Data for male and female were analyzed separately by $t$-test.

increased immobility time has been interpreted as depression-like behavior. Interestingly, female but not male TRH-R2-I- mice exhibited a significant increase in immobility time in TST ( $t$-test; female: $t=2.42, p=0.012$, $N=11+/+$ and $14-/-$; male: $t=1.24, \quad p=0.114$, $N=11+/+$ and $8-/-$; Figure 4). In FST, no significant difference was found but both male and female TRH-R2-Imice showed a trend for increased immobility ( $t$-test; female: $t=1.62, \quad p=0.057$; male: $t=1.47, p=0.076$; Figure 4). These data suggest that female TRH-R2-I- mice have a mild depression-like behavior.

A number of anxiety-related tests are available but only a few of them are validated by various classes of clinically relevant anxiolytics (including benzodiazepines and serotonin reuptake inhibitors). One of these assays is the NIHT (Dulawa et al, 2004). In this test, animals are provided with a familiar and highly palatable food (sweetened milk in our experiments) in a novel and brightly lit environment. In these conditions, animals are conflicted on whether to avoid 


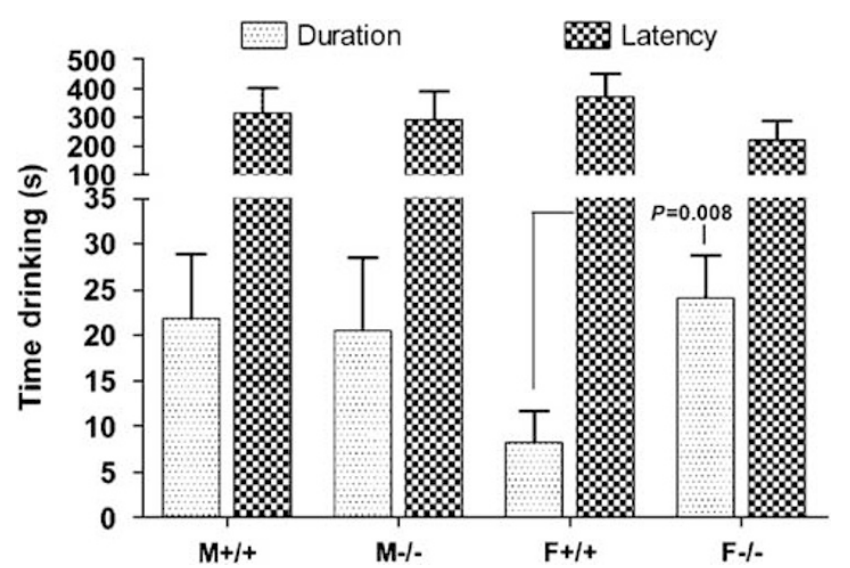

Figure 5 Results of the novelty-induced hypophagia test in wild-type and thyrotropin-releasing hormone receptor type 2 (TRH-R2)-deficient mice. The novelty-induced hypophagia test (NIHT) was performed as described in Materials and methods; durations and latencies of drinking in novel cages were measured. Data for male and female were analyzed separately by t-test.

or approach the food. Heightened fear and anxiety are reflected by an increase in the latency and a decrease in the duration of feeding and clinically used anxiolytics elicit opposite responses (Merali et al, 2003; Dulawa and Hen, 2005). Duration of feeding was significantly increased in female but not in male TRH-R2-I- mice ( $t$-test; female: $t=2.60, p=0.008, N=11+/+$ and $14-/-$; Figure 5). Consistent with a reduced anxiety level in females, the latency to eat was also reduced in female but not in male TRH-R2-I- mice but this effect was only a trend ( $t$-test; female: $t=1.47, p=0.077$; Figure 5). In the familiar home cage environment in the dark, no difference in latency and duration was measured between TRH-R $2+/+$ and TRH-R2-/- littermates in either gender (data not shown) indicating that the observed novel cage effect in females was not due to a difference in motivation to feed.

\section{DISCUSSION}

The role of the TRH/TRH-R system in regulation of the HPT axis is well known and the results of the previous studies in TRH-deficient (Yamada et al, 1997) and TRH-R1-deficient mice (Rabeler et al, 2004; Zeng et al, 2007) and the current studies in TRH-R2-deficient mice show that TRH-R1 is the physiological target of TRH in the TSH-producing cells of the anterior pituitary gland. The role of this system in regulation of glucose homeostasis is less well understood but both TRH- and TRH-R1-deficient mice exhibit hyperglycemia. In contrast, TRH-R2-ko mice exhibit normal glucose homeostasis even when given a high-fat diet. Therefore, TRH regulation of glucose metabolism in rodents (Kulkarni et al, 1995; Yamada et al, 2000; Luo and Yano, 2004) is mediated by TRH-R1. Furthermore, it was suggested that the effect of TRH on glucose homeostasis is mediated, at least in part, by TRH-R1 expressed on insulin-secreting cells. It is noteworthy, therefore, that although TRH-R1 has been reported to be expressed in adult rodent islets at the mRNA and protein levels (Kulkarni et al, 1995; Luo and Yano, 2004), we have found no TRH-R
mRNA in islets of Langerhans from adult humans (Mulla et al, 2008).

Besides its established neuroendocrine role in controlling TSH release, the TRH/TRH-R system has been proposed as a major regulatory system within the central nervous system including a role in the modulation of mood, arousal, and circadian rhythm; functions thought to be impaired or altered in depression and anxiety (Gary et al, 2003; Yarbrough et al, 2007; Sattin, 1999; Pekary et al, 2006; Gutierrez-Mariscal et al, 2008). Here we tested if lack of TRH-R2 results in changes in depression- and anxiety-related behaviors. Both FST and TST indicated a moderate depression-like behavior in female but not male TRH-R2-I- mice. Although no animal model can reproduce the complex symptomatology of depression, it is believed that some aspects or endophenotypes of the disease can be reproduced in animals. In particular, disturbances in the monoamine system have long been implicated in depression and it is thought that FST and TST are assays to detect changes in monoaminergic activity. Indeed, depletion of serotonin increases whereas antidepressantinduced activation of serotonergic and/or noradrenergic neurotransmission reduces immobility time in FST and TST (Porsolt et al, 1978; Page et al, 1999; Cryan et al, 2002). We speculate that the increased immobility of TRH-R2-Imice in the FST and TST indicates reduced serotonergic and/or adrenergic neurotransmission in these mice (Sattin et al, 2008). The depression-like behavior of TRH-R2-Imice is also consistent with the reported antidepressant effect of TRH (Sattin, 1999) although not all studies support this effect (Gary et al, 2003). Another interesting aspect of the depression-like behavior of the TRH-R2 mice is the gender specificity of the phenotype. Not only is depression more prevalent in females, symptoms of major depression show gender differences (Khan et al, 2002).

A large body of human imaging studies and animal experiments suggest that depression and depression-like behavior are associated with a neuronal circuit composed of the anterior cingulate cortex and its connections with the limbic system that includes the amygdala and the hippocampus among other brain regions. TRH-R2 is expressed in these brain areas and it is particularly interesting that this receptor is the sole TRH-R in the cingulate cortex in the rat (O'Dowd et al, 2000). As lesion of the anterior cingulate increases immobility in FST (Bissiere et al, 2008) and because FST activates the immediate early gene $c$-fos in this area (Duncan et al, 1996), we speculate that the absence of TRH-R2 in this region is especially relevant in the depression-like behavior of TRH-R2-I- mice. However, TRH-R2, together with TRH-R1, is also expressed in the amygdala and in the bed nucleus of the stria terminalis, other important regions in the regulation of mood and the function of this receptor pool may also be involved in the emergence of the phenotype in TRH-R2-I- mice. Indeed, the moderate phenotype we observed in TRH-R2-I- mice may be because TRH-R1, which signals through the same pathways as TRH-R2, is present in these regions.

The level of anxiety of TRH-R2 mice was tested in NIHT. Again, only female TRH-R2-I- mice showed abnormalities, specifically increased duration and reduced latency of feeding that are consistent with reduced anxiety. Although the depression-like and reduced anxiety-like behaviors of 
TRH-R2-/-mice seem contradictory because of the comorbidity of mood and anxiety disorders, these phenotypes represent only specific dimensions of these disorders and are uncoupled in some animal models. Indeed, 5-HT1 A receptor and CREB-deficient mice exhibit antidepressantlike and increased anxiety-like phenotypes (Parks et al, 1998; Sibille et al, 2000; Gur et al, 2007).

It is noteworthy that there are prominent similarities between control of central nervous system function by TRH-R1 and TRH-R2 and the better studied two receptor system for corticotropin-releasing hormone (CRH) (see Steckler and Holsboer, 1999 for review). Like TRH-R1/TRH$\mathrm{R} 2, \mathrm{CRH}$ receptor 1 (CRH1) and CRH receptor 2 (CRH2) exhibit different patterns of expression and activate multiple signaling pathways, and have been shown to mediate overlapping but different behaviors including control of mood.

In conclusion, female TRH-R2 ko mice exhibit increased depression-like and reduced anxiety-like phenotypes. Although TRH-R1 ko mice were reported to exhibit increased depression-like and increased anxiety-like behaviors they were hypothyroid and their behavioral changes may have been caused indirectly by hypothyroidism. TRH$\mathrm{R} 2$ is not expressed in the anterior pituitary and TRH-R2-Imice are euthyroid; thus, the data reported herein provide the first evidence of the involvement of extrahypothalamic TRH in regulating depression/anxiety-like behavior in mice and show that TRH-R2 mediates these behaviors.

\section{ACKNOWLEDGEMENTS}

We thank Dr Chuxia Deng, NIDDK Core Knockout Laboratory for advice and help in creating TRH-R2deficient mice. We also thank Dr Oksana Gavrilova, NIDDK Mouse Metabolism Core Laboratory, for advice and help with analysis of growth and glucose/insulin homeostasis in TRH-R2-deficient mice. This work was supported by the Intramural Research Program, NIDDK, NIH and grants 5RO1 MH058669 and 1RO1 MH080194 to MT. BZ was supported by $\mathrm{NIH}$ predoctoral training grant 5T32DA007274.

\section{DISCLOSURE/CONFLICT OF INTEREST}

The authors do not have direct or indirect conflicts of interest or biomedical financial interests to disclose.

\section{REFERENCES}

Alkemade A, Unmehopa UA, Brouwer JP, Hoogendijk WJ, Wiersinga WM, Swaab DF et al (2003). Decreased thyrotropinreleasing hormone gene expression in the hypothalamic paraventricular nucleus of patients with major depression. Mol Psychiatry 8: 838-839.

Bartalena L, Placidi GF, Martino E, Falcone M, Pellegrini L, Dell'Osso L et al (1990). Nocturnal serum thyrotropin (TSH) surge and the TSH response to TSH-releasing hormone: dissociated behavior in untreated depressives. J Clin Endocrinol Metab 71: 650-655.

Bissiere S, Plachta N, Hoyer D, McAllister KH, Olpe HR, Grace AA et al (2008). The rostral anterior cingulate cortex modulates the efficiency of amygdala-dependent fear learning. Biol Psychiatry 63: $821-831$.

Cao J, O'Donnell D, Vu H, Payza K, Pou C, Godbout C et al (1998). Cloning and characterization of a cDNA encoding a novel subtype of rat thyrotropin-releasing hormone receptor. J Biol Chem 273: 32281-32287.

Cryan JF, Markou A, Lucki I (2002). Assessing antidepressant activity in rodents: recent developments and future needs. Trends Pharmacol Sci 23: 238-245.

de la Pena P, Delgado LM, del Camino D, Barros F (1992). Two isoforms of the thyrotropin-releasing hormone receptor generated by alternative splicing have indistinguishable functional properties. J Biol Chem 267: 25703-25708.

Deng C, Wynshaw-Boris A, Zhou F, Kuo A, Leder P (1996). Fibroblast growth factor receptor 3 is a negative regulator of bone growth. Cell 84: 911-921.

Dulawa SC, Hen R (2005). Recent advances in animal models of chronic antidepressant effects: the novelty-induced hypophagia test. Neurosci Biobehav Rev 29: 771-783.

Dulawa SC, Holick KA, Gundersen B, Hen R (2004). Effects of chronic fluoxetine in animal models of anxiety and depression. Neuropsychopharmacology 29: 1321-1330.

Duncan GE, Knapp DJ, Johnson KB, Breese GR (1996). Functional classification of antidepressants based on antagonism of swim stress-induced fos-like immunoreactivity. J Pharmacol Exp Ther 277: 1076-1089.

Duthie SM, Taylor PL, Anderson L, Cook J, Eidne KA (1993). Cloning and functional characterisation of the human TRH receptor. Mol Cell Endocrinol 95: R11-R15.

Gary KA, Sevarino KA, Yarbrough GG, Prange Jr AJ, Winokur A (2003). The thyrotropin-releasing hormone (TRH) hypothesis of homeostatic regulation: implications for TRH-based therapeutics. J Pharmacol Exp Ther 305: 410-416.

Gur TL, Conti AC, Holden J, Bechtholt AJ, Hill TE, Lucki I et al (2007). cAMP response element-binding protein deficiency allows for increased neurogenesis and a rapid onset of antidepressant response. J Neurosci 27: 7860-7868.

Gutierrez-Mariscal M, de Gortari P, Lopez-Rubalcava C, Martinez A, Joseph-Bravo P (2008). Analysis of the anxiolytic-like effect of TRH and the response of amygdalar TRHergic neurons in anxiety. Psychoneuroendocrinology 33: 198-213.

Harder S, Dammann O, Buck F, Zwiers H, Lederis K, Richter D et al (2001a). Cloning of two thyrotropin-releasing hormone receptor subtypes from a lower vertebrate (Catostomus commersoni): functional expression, gene structure, and evolution. Gen Comp Endocrinol 124: 236-245.

Harder S, Lu X, Wang W, Buck F, Gershengorn MC, Bruhn TO (2001b). Regulator of $G$ protein signaling 4 suppresses basal and thyrotropin releasing-hormone (TRH)-stimulated signaling by two mouse TRH receptors, TRH-R(1) and TRH-R(2). Endocrinology 142: 1188-1194.

Itadani H, Nakamura T, Itoh J, Iwaasa H, Kanatani A, Borkowski J et al (1998). Cloning and characterization of a new subtype of thyrotropin-releasing hormone receptors. Biochem Biophys Res Commun 250: 68-71.

Khan AA, Gardner CO, Prescott CA, Kendler KS (2002). Gender differences in the symptoms of major depression in opposite-sex dizygotic twin pairs. Am J Psychiatry 159: 1427-1429.

Kulkarni RN, Wang ZL, Akinsanya KO, Bennet WM, Wang RM, Smith DM et al (1995). Pyroglutamyl-phenylalanyl-proline amide attenuates thyrotropin-releasing hormone-stimulated insulin secretion in perifused rat islets and insulin-secreting clonal beta-cell lines. Endocrinology 136: 5155-5164.

Luo LG, Yano N (2004). Expression of thyrotropin-releasing hormone receptor in immortalized beta-cell lines and rat pancreas. J Endocrinol 181: 401-412.

Matre V, Karlsen HE, Wright MS, Lundell I, Fjeldheim AK, Gabrielsen OS et al (1993). Molecular cloning of a functional 
human thyrotropin-releasing hormone receptor. Biochem Biophys Res Commun 195: 179-185.

Merali Z, Levac C, Anisman H (2003). Validation of a simple, ethologically relevant paradigm for assessing anxiety in mice. Biol Psychiatry 54: 552-565.

Mulla CM, Geras-Raaka E, Raaka BM, Gershengorn MC (2008). High levels of TRH receptors activate programmed cell death in human pancreatic precursors. Pancreas 2009 (in press).

O'Dowd BF, Lee DK, Huang W, Nguyen T, Cheng R, Liu Y et al (2000). TRH-R2 exhibits similar binding and acute signaling but distinct regulation and anatomic distribution compared with TRH-R1. Mol Endocrinol 14: 183-193.

Page ME, Detke MJ, Dalvi A, Kirby LG, Lucki I (1999). Serotonergic mediation of the effects of fluoxetine, but not desipramine, in the rat forced swimming test. Psychopharmacology (Berl) 147: 162-167.

Parks CL, Robinson PS, Sibille E, Shenk T, Toth M (1998). Increased anxiety of mice lacking the serotonin1A receptor. Proc Natl Acad Sci USA 95: 10734-10739.

Pekary AE, Faull KF, Paulson M, Lloyd RL, Sattin A (2005). TRHlike antidepressant peptide, pyroglutamyltyroslyprolineamide, occurs in rat brain. J Mass Spectrom 40: 1232-1236.

Pekary AE, Stevens SA, Sattin A (2006). Circadian rhythms of TRH-like peptide levels in rat brain. Brain Res 1125: 67-76.

Porsolt RD, Bertin A, Jalfre M (1978). 'Behavioural despair' in rats and mice: strain differences and the effects of imipramine. Eur J Pharmacol 51: 291-294.

Rabeler R, Mittag J, Geffers L, Ruther U, Leitges M, Parlow AF et al (2004). Generation of thyrotropin-releasing hormone receptor 1deficient mice as an animal model of central hypothyroidism. Mol Endocrinol 18: 1450-1460.

Sattin A (1999). The role of TRH and related peptides in the mechanism of action of ECT. J Ect 15: 76-92.

Sattin A, Pekary AE, Blood J (2008). Escitalopram regulates expression of TRH and TRH-like peptides in rat brain and peripheral tissues. Neuroendocrinology 88: 135-146.

Sellar RE, Taylor PL, Lamb RF, Zabavnik J, Anderson L, Eidne KA (1993). Functional expression and molecular characterization of the thyrotrophin-releasing hormone receptor from the rat anterior pituitary gland. J Mol Endocrinol 10: 199-206.

Sibille E, Pavlides C, Benke D, Toth M (2000). Genetic inactivation of the serotonin $(1 \mathrm{~A})$ receptor in mice results in downregulation of major $\mathrm{GABA}(\mathrm{A})$ receptor alpha subunits, reduction of
GABA(A) receptor binding, and benzodiazepine-resistant anxiety. J Neurosci 20: 2758-2765.

Steckler T, Holsboer F (1999). Corticotropin-releasing hormone receptor subtypes and emotion. Biol Psychiatry 46: 1480-1508.

Straub RE, Frech GC, Joho RH, Gershengorn MC (1990). Expression cloning of a cDNA encoding the mouse pituitary thyrotropin-releasing hormone receptor. Proc Natl Acad Sci USA 87: 9514-9518.

Sun Y, Lu X, Gershengorn MC (2003). Thyrotropin-releasing hormone receptors - similarities and differences. J Mol Endocrinol 30: 87-97.

Sun YM, Millar RP, Ho H, Gershengorn MC, Illing N (1998). Cloning and characterization of the chicken thyrotropinreleasing hormone receptor. Endocrinology 139: 3390-3398.

Takata M, Shimada Y, Ikeda A, Sekikawa K (1998). Molecular cloning of bovine thyrotropin-releasing hormone receptor gene. $J$ Vet Med Sci 60: 123-127.

Yamada M, Saga Y, Shibusawa N, Hirato J, Murakami M, Iwasaki T et al (1997). Tertiary hypothyroidism and hyperglycemia in mice with targeted disruption of the thyrotropin-releasing hormone gene. Proc Natl Acad Sci USA 94: 10862-10867.

Yamada M, Shibusawa N, Hashida T, Ozawa A, Monden T, Satoh T et al (2000). Expression of thyrotropin-releasing hormone (TRH) receptor subtype 1 in mouse pancreatic islets and HIT-T15, an insulin-secreting clonal beta cell line. Life Sci 66: $1119-1125$.

Yang X, Li C, Xu X, Deng C (1998). The tumor suppressor SMAD4/ DPC4 is essential for epiblast proliferation and mesoderm induction in mice. Proc Natl Acad Sci USA 95: 3667-3672.

Yarbrough GG, Kamath J, Winokur A, Prange Jr AJ (2007). Thyrotropin-releasing hormone (TRH) in the neuroaxis: therapeutic effects reflect physiological functions and molecular actions. Med Hypotheses 69: 1249-1256.

Zeng H, Schimpf BA, Rohde AD, Pavlova MN, Gragerov A, Bergmann JE (2007). Thyrotropin-releasing hormone receptor 1deficient mice display increased depression and anxiety-like behavior. Mol Endocrinol 21: 2795-2804.

Zhao D, Yang J, Jones KE, Gerald C, Suzuki Y, Hogan PG et al (1992). Molecular cloning of a complementary deoxyribonucleic acid encoding the thyrotropin-releasing hormone receptor and regulation of its messenger ribonucleic acid in rat $\mathrm{GH}$ cells. Endocrinology 130: 3529-3536. 